\title{
Seasonal variations in aerosol particle composition at the puy-de-Dôme research station in France
}

\author{
E. J. Freney ${ }^{1}$, K. Sellegri ${ }^{1}$, F. Canonaco ${ }^{2}$, J. Boulon ${ }^{1}$, M. Hervo ${ }^{1}$, R. Weigel ${ }^{1, *}$, J. M. Pichon ${ }^{1}$, A. Colomb ${ }^{1}$, \\ A. S. H. Prévôt ${ }^{2}$, and P. Laj ${ }^{1, * *}$ \\ ${ }^{1}$ Laboratoire de Météorologie Physique, CNRS-Université Blaise Pascal, UMR6016, 63117, Clermont Ferrand, France \\ ${ }^{2}$ Laboratory of Atmospheric Chemistry, Paul Scherrer Institut, 5232 Villigen, Switzerland \\ * now at: Institute for Physics of the Atmosphere, Johannes Gutenberg University Mainz, Germany \\ ***now at: Laboratoire de Glaciologie et Géophysique de l'Environnement, CNRS UMR5183, Université Joseph Frourier \\ Grenoble 1, Saint Martin d'Héres, France
}

Received: 8 August 2011 - Published in Atmos. Chem. Phys. Discuss.: 4 October 2011

Revised: 13 December 2011 - Accepted: 13 December 2011 - Published: 21 December 2011

\begin{abstract}
Detailed investigations of the chemical and microphysical properties of atmospheric aerosol particles were performed at the puy-de-Dôme (pdD) research station $(1465 \mathrm{~m})$ in autumn (September and October 2008), winter (February and March 2009), and summer (June 2010) using a compact Time-of-Flight Aerosol Mass Spectrometer (cToFAMS). Over the three campaigns, the average mass concentrations of the non-refractory submicron particles ranged from $10 \mu \mathrm{g} \mathrm{m}^{-3}$ up to $27 \mu \mathrm{g} \mathrm{m}^{-3}$. Highest nitrate and ammonium mass concentrations were measured during the winter and during periods when marine modified airmasses were arriving at the site, whereas highest concentrations of organic particles were measured during the summer and during periods when continental airmasses arrived at the site. The measurements reported in this paper show that atmospheric particle composition is strongly influenced by both the season and the origin of the airmass. The total organic mass spectra were analysed using positive matrix factorisation to separate individual organic components contributing to the overall organic particle mass concentrations. These organic components include a low volatility oxygenated organic aerosol particle (LV-OOA) and a semi-volatile organic aerosol particle (SV-OOA). Correlations of the LV-OOA components with fragments of $\mathrm{m} / \mathrm{z}, 60$ and $\mathrm{m} / \mathrm{z} 73$ (mass spectral markers of wood burning) during the winter campaign suggest that wintertime LV-OOA are related to aged biomass burning emissions, whereas organic aerosol particles measured during the
\end{abstract}

Correspondence to: E. J. Freney (e.freney@opgc.univ-bpclermont.fr) summer are likely linked to biogenic sources. Equivalent potential temperature calculations, gas-phase, and LIDAR measurements define whether the research site is in the planetary boundary layer (PBL) or in the free troposphere (FT)/residual layer (RL). We observe that SV-OOA and nitrate particles are associated with air masses arriving from the PBL where as particle composition measured from RL/FT airmasses contain high mass fractions of sulphate and LV-OOA. This study provides unique insights into the effects of season and airmass variability on regional aerosol particles measured at an elevated site.

\section{Introduction}

Submicron atmospheric aerosols exert a highly uncertain effect on radiative climate forcing and can have serious impacts on human health. For this reason, detailed and long-term analysis of the physicochemical properties of atmospheric aerosol particles is crucial to understand their processes and lifetime in the atmosphere. A network of both high $(>2000 \mathrm{~m})$ and low $(<1000 \mathrm{~m})$ elevation measurement sites have provided the opportunity to study the long-term variability of aerosol particle properties in Europe. These urban and rural research sites are most commonly equipped with size distribution measurements and filters for offline particle composition measurements (Nyeki et al., 1998; Weingartner et al., 1999; Gelencser et al., 2007; Venzac et al., 2009).

Results arising from observations made at these research sites offer information on the seasonal and chemical variability of aerosol particles measured in different atmospheric

Published by Copernicus Publications on behalf of the European Geosciences Union. 
environments. However, the coarse time and size resolution of these measurements limits our knowledge on the physical and chemical properties of aerosol particles. In the last decade, online aerosol mass spectrometers have been used to provide highly time resolved quantitative data on submicron inorganic and organic aerosol species. There have recently been several reports summarizing aerosol mass spectrometry measurements made in the Northern Hemisphere (Zhang et al., 2005; Jimenez et al., 2009; Ng et al., 2010), showing that aged organic compounds are the largest contributor to the submicron particle mass. In Europe, Lanz et al. (2010) overviewed the results of several campaigns carried out in the alpine region over a number of different seasons, providing detailed information on the aerosol particle chemical and physical properties at both high- and low-altitude sites and during several different seasons of the year. Similar to previous observations they showed that organic compounds were the most abundant species in the submicron particle fraction, with biomass burning organic aerosol particles being important during the winter and low-volatility organic aerosol (LVOOA) dominating during the spring and summer. Although these studies provide information on the background composition during different seasons they are unable to provide information on the seasonal variability at the same site.

The puy-de-Dôme (pdD) research site is classified as a mid-altitude site $(1465 \mathrm{~m})$ where at night the research site is commonly in the residual layer (RL) or in the free troposphere (FT), but during the day it is exposed to airmasses arriving from the planetary boundary layer (PBL) (Venzac et al., 2009). Therefore, at the pdD site, measured particle composition during the day can be representative of boundary layer air masses, whereas at night particle composition is representative of regional air masses. These features make the pdD research site an ideal place to characterise both regional and local boundary layer pollution conditions through examining the diurnal variability of aerosol particle properties. A compact Time-of-Flight Aerosol Mass Spectrometer (cToF-AMS) was deployed at the pdD site during three different seasons of the year as part of the European monitoring and evaluation program (EMEP). The aim of EMEP is to characterise the physical and chemical properties of the aerosol population in Europe through carrying out simultaneous aerosol composition measurements at several different research sites. In this paper, we report the chemical composition, concentrations, and temporal variations of the nonrefractory particle components at the pdD site. The focus of this study was to characterise the seasonal variability in the chemistry of both long-range transported and less aged PBL airmasses with high-time resolution, and thereby offering insights into the sources and properties of aerosol particles arriving at an elevated background site.

\section{Experimental}

\subsection{Sampling site}

The pdD research station is located in central France $\left(45^{\circ} 46 \mathrm{~N}, 2^{\circ} 57 \mathrm{E}\right)$. The station is surrounded by agricultural and forest areas. The city of Clermont-Ferrand (150000 inhabitants) is located $16 \mathrm{~km}$ east of the station at $396 \mathrm{~m}$. A detailed description of the site is provided by Venzac et al. (2009). The pdD research site contains a number of different instruments capable of resolving the physical, chemical, optical, and hygroscopic properties of aerosol particles. The site is in cloud approximately $50 \%$ of the time between November and March. For this reason the site is equipped with two different types of stainless steel inlets; a whole air inlet capable of sampling cloud droplets together with interstitial (non-activated) particles (whole air inlet (WAI)), and a second inlet capable of sampling only interstitial particles. The WAI inlet has a $50 \%$ cut-off at $30 \mu \mathrm{m}$ and the interstitial inlet has a $50 \%$ cut-off at $1.6 \mu \mathrm{m}$. These inlets do not allow for isokinetic sampling. Meteorological parameters (including wind direction, wind speed, relatively humidity (RH), pressure, and temperature), aerosol physical and chemical properties (particle size, black carbon mass), and gas-phase species $\left(\mathrm{SO}_{2}, \mathrm{CO}, \mathrm{CO}_{2}, \mathrm{O}_{3}, \mathrm{NO}\right.$, and $\left.\mathrm{NO}_{2}\right)$ are measured continuously throughout the year. Particle size distributions between 20 and $800 \mathrm{~nm}$ were measured using a scanning mobility particle sizer (SMPS), and the black carbon (BC) mass concentration was measured using a Multi Angle Absorption Photometer (MAAP 5012). The SMPS and MAAP were sampling behind the WAI, whereas the AMS was situated behind the interstitial inlet.

\subsection{Backward trajectories}

In order to determine the transport pathways of the aerosol particles prior to arriving at the pdD site (1465 m), the Hybrid Single Particle Langrangian Trajectory (HYSPLIT) model was used. Seventy-two hour backward trajectories were computed for every hour for each day of the campaign. Trajectories were classified according to their predominant transport direction prior to measurement as either continental (C), marine (M), marine modified (Mod), and Mediterranean (Med) (Fig. S1). If air mass trajectories show a combination of transport direction during the 72-h period the air mass is classified as mixed.

\subsection{LIDAR and temperature profile measurements}

Using temperature, pressure, and relative humidity data from measurements made simultaneously at the Observatoire de Physique du Globe de Clermont-Ferrand (OPGC) ground based research station ( $425 \mathrm{~m}$ a.s.1., $11 \mathrm{~km}$ east from the $\mathrm{pdD}$ Research Station) and at the pdD site, the differential equivalent potential temperature $(\theta e)$ was calculated as a function of elevation using the Boltons approximation (Bolton, 1980). 
The calculated $(\theta e)$ is used to identify if the measurements at the pdD site were performed in the PBL, FT, or RL. Figure 1, shows the correlation of $\theta e$ at the OPGC with those at the pdD site coloured by hour of day for the three different campaigns. The largest difference in $\theta e$ between the two sites occurs during the evening hours. This difference is most pronounced during the winter campaign when the pdD is most often in the free troposphere. During the summer campaign, LIDAR measurements were also available (Fig. 1d). The spatial raw resolution of the detected signals is $15 \mathrm{~m}$. The LIDAR instrument is positioned on the roof of the OPGC. There was no cloud cover over the OPGC or pdD during the LIDAR measurements. The boundary layer height was determined by a wavelength covariance technique (Brooks, 2003), and exhibit a weak diurnal variation in boundary layer height. However, these measurements show that during the summer, the pdD site was always sampling in the PBL or RL.

\subsection{Time-of-flight aerosol mass spectrometer}

The chemical composition and mass concentration of the non-refractory submicron particulate matter (NR-PM1) was measured with an Aerodyne cToF-AMS (Drewnick et al., 2005; Canagaratna et al., 2007). In order to extract chemically resolved mass concentrations of individual aerosol species, the AMS raw data are evaluated with standard assumptions as described by Allan et al. (2004). Filter measurements, in which the AMS sampled filtered air, were made approximately every $48 \mathrm{~h}$. The resolved mass concentrations include ammonium, sulphate, nitrate, organic, and chloride species. For the organic mass spectra additional analysis was carried out using positive matrix factorisation (PMF). The cToF-AMS was sampling behind an interstitial inlet. For this reason, when the site was advected by clouds, the cToF-AMS sampled only those particles not activated into clouds. For the purpose of this study only periods when the site was not in cloud are taken into account.

The calculation of the mass concentrations from the cToFAMS mass spectra requires that a collection efficiency (CE) be applied to the data. The CE is defined as the fraction of the particle mass that is measured by the cToF-AMS, relative to what would have been measured if all particles were spherical and particle bounce was negligible. Recently, it has been demonstrated that particles containing high ammonium nitrate concentrations are more efficiently sampled by the AMS than other inorganic and organic species (Middlebrook et al., 2012). Ammonium nitrate particles tend to be spherical and retain water even at very low RH values and are therefore efficiently focused by the particle beam and are not subjected to particle losses from particle bounce (Middlebrook et al., 2012). Middlebrook et al. (2012) illustrated, using a series of equations, how a composition dependent CE can be applied to particle mass concentrations. Middlebrook et al. (2012) uses a constant CE of 0.45 for an ammonium nitrate mass fraction $(\mathrm{ANMF})<0.4$ and a linear $\mathrm{CE}$ increase up to 1 for ANMF > 0.4. In this study, a similar composition dependent $\mathrm{CE}$ is applied to the data.

$\mathrm{CE}_{\mathrm{DRY}}=\max (0.5,0.264+0.943 \times \mathrm{ANMF})$

in which a constant $\mathrm{CE}$ of 0.5 is used for $\mathrm{ANMF}<0.25$ and a linear $\mathrm{CE}$ increase up to 1 for $\mathrm{ANMF}>0.25$. Since the majority of aerosol particles arriving at the pdD site are thought to be internally mixed, this composition dependent CE was applied to all species sampled by the AMS. A time series of the composition dependent $\mathrm{CE}$ for each campaign is illustrated in Fig. S2. In order to assess how accurate our chosen $\mathrm{CE}$ was at quantifying the mass of aerosol particles in the atmosphere, we compared the total volume of aerosol particles sampled by the AMS and BC with that sampled by a SMPS. The AMS volume was calculated by dividing the mass concentrations of organic and inorganic species by their respective densities $\left(1.72 \mu \mathrm{g} \mathrm{cm}^{-3}\right.$ for $\mathrm{SO}_{4}$, $\mathrm{NH}_{4}, \mathrm{NO}_{3}, 1.2 \mu \mathrm{g} \mathrm{cm}^{-3}$ for organics, and $1.8 \mu \mathrm{g} \mathrm{cm}^{-3}$ for BC). During this study, the SMPS was sampling behind a WAI inlet, where as the AMS was sampling behind the interstitial inlet and hence the AMS did not sample particles with the same efficiency as the SMPS. In addition the SMPS was not sampling in the same building at the time of the respective campaigns. The resulting slopes and $r^{2}$, respectively for each comparison were as follows; $\mathrm{Au}-$ tumn, slope $=0.76$ and $r^{2}=0.44$ (the calculated ratio between SMPS:AMS for the whole period was measured at 0.95 ), Winter, slope $=0.51$ and $r^{2} 0.71$ (the average ratio of SMPS:AMS $=1.61$ ), and summer slope $=0.68$ and $r^{2}=44$ (the average ratio of SMPS:AMS $=0.85$ ) for the autumn, winter, and summer, respectively (Fig. S3). Periods with largest discrepancies were observed during episodes when increased particle numbers were sampled by the SMPS. The size distributions of all particles during all seasons arriving at $\mathrm{pdD}$ are characteristic of aged particles showing a major accumulation mode peaking at an aerodynamic diameter of $600 \mathrm{~nm}$ (Fig. S4). This monomodal peak is expected since the site is not exposed to fresh emissions but rather to particles transported long distances and thus considerably aged.

\subsection{Positive matrix factorisation}

The unit mass resolution organic mass spectra from the cToFAMS instrument are analysed using positive matrix factorisation (PMF). PMF is a statistical technique in which the organic mass spectral time series $(X)$ are represented as a linear combination of a set of characteristic factor profiles $(F)$ and their time-dependant intensities $(G)$ (Paatero and Tapper, 1994; Paatero, 1997). PMF is therefore described by the matrix equation $\mathbf{X}=\mathbf{G F}+\mathbf{E}$, where $\mathbf{E}$ is the residual matrix, defined as the difference between the data matrix $\mathbf{X}$ and the fitted solution GF. The PMF analysis was conducted using PMF2 software package (P. Paatero, University of Helsinki, Finland), together with the PMF analysis and evaluation tool (Ulbrich et al., 2009). The error matrix 

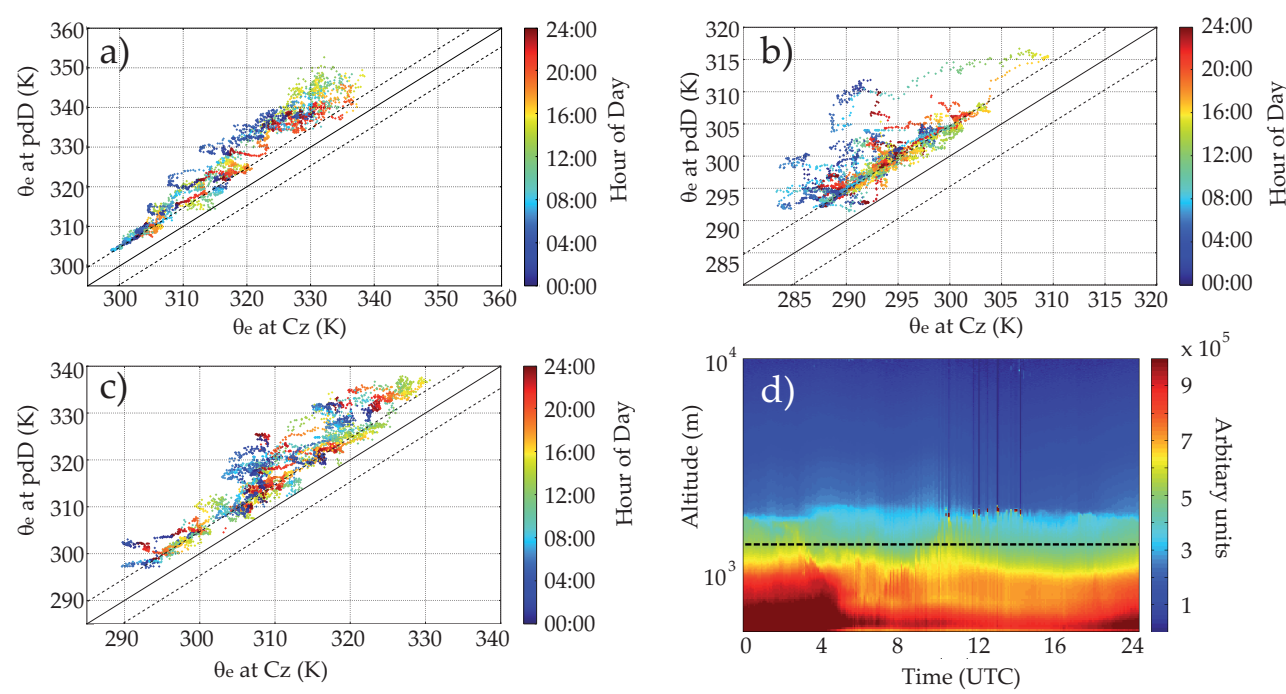

Fig. 1. Equivalent potential temperature $(\theta e)$ determined from meteorological parameters measured at pdD and at the OPGC for the (a) autumn, (b) winter, and (c) summer campaign coloured by hour of day (UTC). (d) Lidar image, coloured by range-corrected signal at $355 \mathrm{~nm}$ (arbitrary units) taken during the summer campaign showing that the pdD station was always in the boundary layer (values greater than $3 \times 105)$. The dark dotted line represents to the height of the pdD (1465 $\mathrm{m}$ a.s.l).

calculated in the Squirrel software (version 1.51) was modified following the recommendations of Ulbrich et al. (2009) and references therein. A minimum error of 1 ion was applied throughout the $\mathbf{X}$ matrix, and the organic peaks calculated as the fraction of the $\mathrm{CO}_{2}^{+}$ion $(\mathrm{m} / z, 44,18,17$, and 16) were down weighted as described in Ulbrich et al. (2009). Matrix rotations were explored by varying the $f_{\text {peak }}$ parameter from -3 to +3 . The $f_{\text {peak }}$ parameter allows the user to explore different PMF solutions that give the same fit to the data (Ulbrich et al., 2009). The number of PMF factors and $f_{\text {peak }}$ values were determined by minimising the scaled residuals and factor correlations with external tracers (including $\mathrm{CO}$, $\mathrm{O}_{3}, \mathrm{NO}_{\mathrm{x}}, \mathrm{SO}_{2}, \mathrm{NO}_{3}^{-}$, and $\mathrm{SO}_{4}^{2}-$ ) and comparing the component mass spectra with reference mass spectra available on the AMS mass spectral database (Lanz et al., 2007; Ulbrich et al., 2009). A $f_{\text {peak }}$ value at which a local minimum in the solution space $\left(Q / Q_{\text {exp }}\right)$ was achieved is used to represent each database (Fig. S5). An optimum $f_{\text {peak }}$ value of 0 was applied for each dataset. Correlations of the resolved mass spectral profiles with reference mass spectra and correlations of the organic time series with the time series of other particulate and gas phase species are supplied in the supplementary material (Table S1).

\section{Results and discussion}

\subsection{Characterisation of the submicron particle composition}

A time series of sulphate $\left(\mathrm{SO}_{4}\right)$, nitrate $\left(\mathrm{NO}_{3}\right)$, ammonium $\left(\mathrm{NH}_{4}\right)$, organics $(\mathrm{Org})$, chloride $(\mathrm{Cl})$, and black carbon (BC)- bearing particles is shown in Fig. 2. Meteorological parameters are listed in Table 1. Average values for each aerosol particle species measured by the AMS, during clear sky periods are listed in Table 2. The weather conditions during this study were characterized by high $\mathrm{RH}(86 \pm 12 \%)$ and temperatures ranging from $0.1^{\circ} \mathrm{C}$ to $18^{\circ} \mathrm{C}$ (average $=$ $9 \pm 4^{\circ} \mathrm{C}$ ), $-8^{\circ} \mathrm{C}$ to $13^{\circ} \mathrm{C}$ (average $=1 \pm 4^{\circ} \mathrm{C}$ ), and $2^{\circ} \mathrm{C}$ to $25^{\circ} \mathrm{C}$ (average $=14 \pm 5^{\circ} \mathrm{C}$ ), during the autumn, winter, and summer campaigns, respectively. Highest average aerosol mass concentrations were observed during the summer campaign $\left(27 \mu \mathrm{g} \mathrm{m}^{-3}\right)$ and lowest during the winter campaign $\left(10 \mu \mathrm{g} \mathrm{m}^{-3}\right)$, in agreement with seasonal variability observed at the site for particle number concentrations (Venzac et al., 2009) and particle mass concentrations measured at other high-altitude stations in Europe (Kasper and Puxbaum, 1998; Weingartner et al., 1999).

On the basis of campaign averages and in the order of the campaigns (autumn 2008, winter 2009, summer 2010), the organic mass contributed $32 \%\left(2.52 \mu \mathrm{g} \mathrm{m}^{-3}\right), 23 \%$ $\left(1.24 \mu \mathrm{g} \mathrm{m}^{-3}\right)$, and $56 \%\left(15.59 \mu \mathrm{g} \mathrm{m}^{-3}\right)$ to the NR-PM1. Sulphate particles contributed between $30 \%\left(2.4 \mu \mathrm{g} \mathrm{m}^{-3}\right)$, $22 \%\left(1.28 \mu \mathrm{g} \mathrm{m}^{-3}\right)$, and $20 \%\left(5.45 \mu \mathrm{g} \mathrm{m}^{-3}\right)$, and nitrate contributed $15 \%\left(1.14 \mu \mathrm{g} \mathrm{m}^{-3}\right), 31 \%\left(1.71 \mu \mathrm{g} \mathrm{m}^{-3}\right)$, and $9 \%$ $\left(2.33 \mu \mathrm{g} \mathrm{m}^{-3}\right)$. Ammonium contributed $18 \%\left(1.36 \mu \mathrm{g} \mathrm{m}^{-3}\right)$, $20 \%\left(1.08 \mu \mathrm{g} \mathrm{m}^{-3}\right)$, and $13 \%\left(3.69 \mu \mathrm{g} \mathrm{m}^{-3}\right)$. Chloride always contributed less than $1 \%(0.04)$ and $\mathrm{BC}$ contributed $5 \%\left(0.38 \mu \mathrm{g} \mathrm{m}^{-3}\right), 2 \%\left(0.2 \mu \mathrm{g} \mathrm{m}^{-3}\right)$, and $2 \%\left(0.47 \mu \mathrm{g} \mathrm{m}^{-3}\right)$ (Table 2). Although BC species are sampled behind an inlet with a cut-off diameter of $30 \mu \mathrm{m}$, it has been demonstrated that nearly all of the $\mathrm{BC}$ mass measured at the pdD site have diameters less than $1 \mu \mathrm{m}$ (Sellegri et al., 2003). It is therefore assumed to contribute only to the submicron mass. Organic 
Table 1. Average meteorological parameters and particle number concentration measured at the pdD site for each of the campaigns. The errors represent one standard deviation.

\begin{tabular}{lrrrrrr}
\hline & & & & \multicolumn{2}{c}{ Particle concentration (SMPS) (cm $\left.{ }^{-3}\right)$} \\
\cline { 5 - 6 } Season & Temp $^{\circ} \mathrm{C}$ & RH & Wind speed $\left(\mathrm{ms}^{-1}\right)$ & UV & Day & Night \\
\hline Autumn & $9 \pm 4$ & $86 \% \pm 18$ & $6 \pm 4$ & $5 \pm 7$ & $3018 \pm 1969$ & $2003 \pm 1259$ \\
Winter & $1 \pm 4$ & $86 \% \pm 21$ & $7 \pm 4$ & $5 \pm 7$ & $1557 \pm 1443$ & $1301 \pm 1160$ \\
Summer & $14 \pm 5$ & $87 \% \pm 12$ & $2.2 \pm 1.2$ & $9 \pm 11$ & $3405 \pm 1156$ & $3364 \pm 1108$ \\
\hline
\end{tabular}

Table 2. The fractional contribution of each species to the total submicron particle mass (\%) and their corresponding average mass concentrations $\left(\mu \mathrm{g} \mathrm{m}^{-3}\right)$. The value shown for each of the separated organic species (LVOOA and SV-OOA) is the fractional contribution of these species to the total organics.

\begin{tabular}{llrrrrrrrr}
\hline Season & & $\mathrm{SO}_{4}$ & $\mathrm{NO}_{3}$ & $\mathrm{NH}_{4}$ & $\mathrm{Chl}$ & $\mathrm{Org}$ & $\mathrm{BC}$ & LV-OOA & SV-OOA \\
\hline \multirow{2}{*}{ Autumn } & $\%$ & 30 & 15 & 18 & 0.3 & 32 & 5 & 73 & 27 \\
& $\mu \mathrm{g} \mathrm{m}^{-3}$ & 2.4 & 1.14 & 1.36 & 0.02 & 2.52 & 0.38 & 1.27 & 0.48 \\
\hline \multirow{2}{*}{ Winter } & $\%$ & 23 & 31 & 20 & 1 & 23 & 2 & 52 & 48 \\
& $\mu \mathrm{g} \mathrm{m}^{-3}$ & 1.28 & 1.71 & 1.08 & 0.07 & 1.24 & 0.2 & 0.412 & 0.418 \\
\hline \multirow{2}{*}{ Summer } & $\%$ & 20 & 9 & 13 & 0.2 & 56 & 2 & 68 & 32 \\
& $\mu \mathrm{g} \mathrm{m}^{-3}$ & 5.45 & 2.33 & 3.69 & 0.06 & 15.59 & 0.474 & 7.82 & 3.76 \\
\hline
\end{tabular}

particle mass concentrations measured during the summer are similar to those observed at other sites during the summer (Lanz et al., 2010), but are much higher than those measured during the autumn and winter campaign at the pdD.

Particle composition measurements made during spring and summer months at elevated (Jungfraujoch) and remote (Hohenpeissenberg) sites in Europe (Hock et al., 2008; Hueglin et al., 2009; Lanz et al., 2010) report Org ranging from $43 \%$ to $50 \%, \mathrm{SO}_{4}$ ranging from $26 \%$ to $19 \%, \mathrm{NO}_{3}$ ranging from $18 \%$ to $19 \%$ and $\mathrm{NH}_{4}$ contributing between $13 \%$ and $11 \%$. Lanz et al. (2010) measured similar particle compositions during the winter at a low altitude site as those measured at high altitude during the summer, suggesting that the type of site (Alpine valleys, elevated sites in the Alps, or Plateau sites) is more important than where the site is situated (rural vs urban) for describing particle composition. Particle mass concentrations measured at the $\mathrm{pdD}$ are similar to those of Lanz et al. (2010) for the summer period showing a high contribution of organic material, however for the winter we see marked differences in particle composition with a significant decrease in the contribution of organic particles (from $56 \%$ (summer) to $23 \%$ (winter)), as well as significant increases in the contributions of nitrate particles (from $8 \%$ (summer) to $31 \%$ (winter)). This shows that there are strong seasonal influences on aerosol particle composition and should be considered when estimating the particle composition during different seasons of the year. The time series of the NR-PM1 chemical components sampled within a given campaign generally had similar trends and varia- tions. During these measurements, ion balance is achieved for $\mathrm{NH}_{4}, \mathrm{NO}_{3}$, and $\mathrm{SO}_{4}$, if $\mathrm{NO}_{3}$ is assumed to be from $\mathrm{NH}_{4} \mathrm{NO}_{3}$, and $\mathrm{SO}_{4}$ is assumed to be from $\left(\mathrm{NH}_{4}\right)_{2} \mathrm{SO}_{4}$. This is illustrated in Fig. S6 where the plot of the measured $\mathrm{NH}_{4}$ vs predicted $\mathrm{NH}_{4}$ falls along the 1:1 line. This shows that aerosol particles measured by the AMS are fully neutralised by ammonium and there are no acidic aerosol particles.

During the autumn, winter, and summer campaigns the $\mathrm{NH}_{4}$ correlate with $\mathrm{NO}_{3}\left(r^{2}=0.67,0.97\right.$, and 0.32 respectively) and $\mathrm{SO}_{4}\left(r^{2}=0.68,0.85\right.$, and 0.78 , respectively). The organic aerosol species are correlated with the inorganic species during the autumn (average $r^{2}$ with $\mathrm{SO}_{4}, \mathrm{NO}_{3}$, and $\mathrm{NH}_{4}=0.55$ ), and winter (average $r^{2}$ with $\mathrm{SO}_{4}, \mathrm{NO}_{3}$, and $\mathrm{NH}_{4}$ is 0.62 ), however, during the summer these $r^{2}$ correlations decreased to approximately 0.15 for $\mathrm{NH}_{4}$ and $\mathrm{SO}_{4}$ and to $<0.01$ for $\mathrm{NO}_{3}$ bearing particles because of the high contributions of organic aerosol particles to the submicron mass. This might indicate different origins like biogenic precursors for secondary organic aerosols versus anthropogenic precursors for the inorganic components. The strong correlations $\left(r^{2}>0.65\right)$ among the inorganic species during the autumn, winter, and summer suggests that the inorganic species are mostly internally mixed. However, the lower correlation between organic and inorganic species suggests that some fraction of the organic species remain externally mixed. Given the sample size for each experiment, any $r^{2}>0.2$ can be considered statistically relevant (the critical value for $r^{2}$ is 0.021 , with a significance level of 0.001 ). 

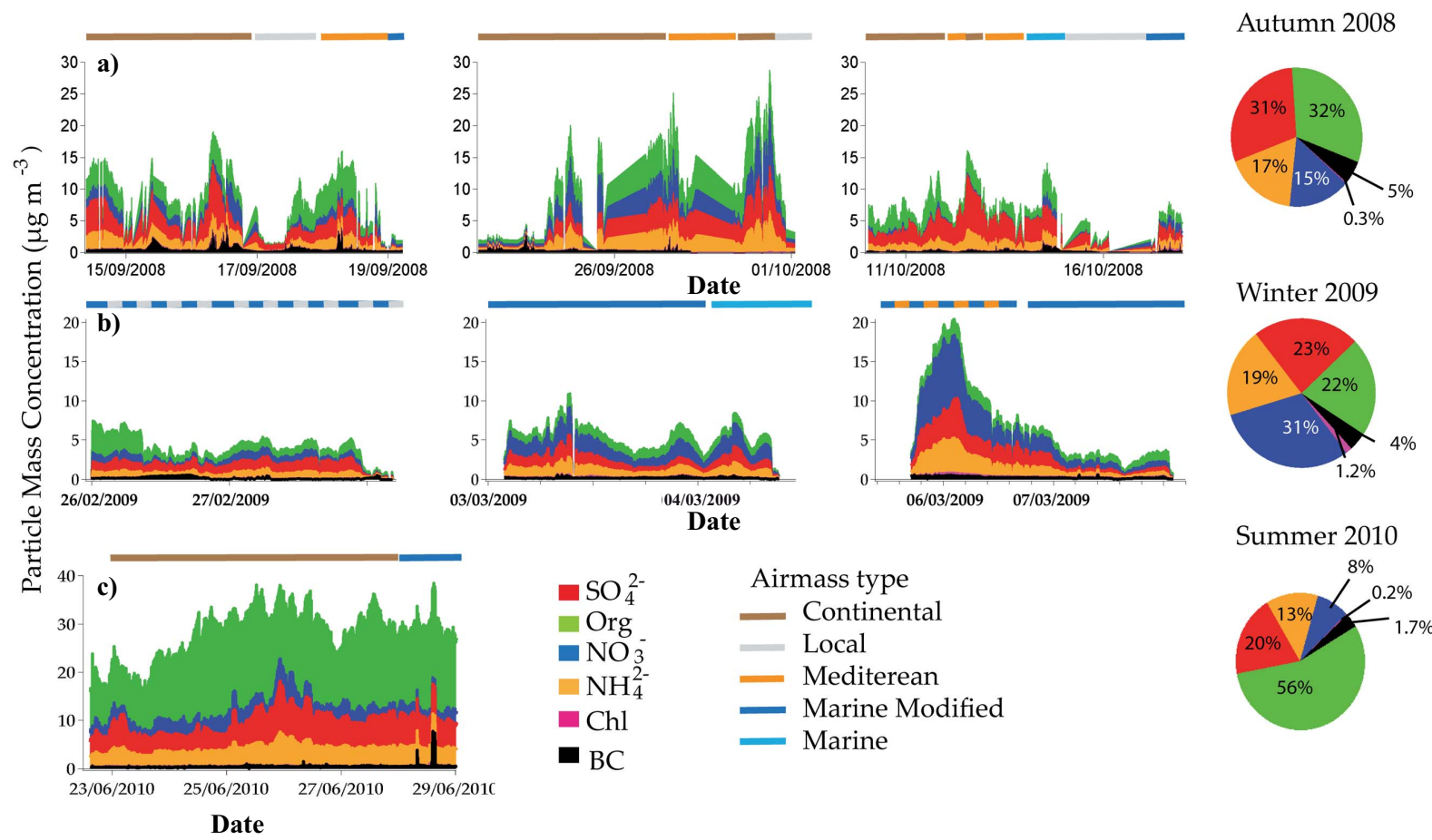

Summer 2010

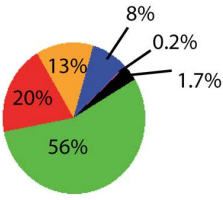

Fig. 2. Mass concentration of organic and inorganic particles measured by the AMS, and BC measured by MAAP during autumn, winter, and summer. Pie charts illustrate the average particle composition measured during each campaign. Coloured bars at the top of each graph indicate the source of the airmass. When the bars are multicoloured it indicates that the airmasses were mixed during this period of sampling.

\subsection{PMF analysis of organic fraction}

In order to fully characterize the organic fraction collected at pdD, PMF analysis was performed separately on each of the datasets, however the resolved PMF factors were similar during all seasons allowing for a direct comparison of the datasets. The number of factors chosen from the PMF analysis was based on the temporal evolution of each of the organic species as well as changes in their mass spectral properties. Two different types of organic compounds were chosen to adequately represent the organic particle fraction at the pdD site. A PMF solution for three factors is shown in Figs. S7 and S8. However, we believe that there is no significant change in the temporal evolution and in the mass spectral properties of each of the organic species when going from a two to a three factor solution, and we therefore chose the two factor PMF solution. The resulting mass spectra and time series of each of the different components resolved during each campaign are illustrated in Fig. 3 and Fig. S9, respectively. A full list of correlations of all PMF components with reference mass spectra and with gas and particle phase species is available in the supplementary material (Table S1). The average mass concentrations and fractional contributions of the different organic components are shown in Table 2. Only oxidised organic aerosol (OOA) particles were resolved from cToF-AMS measurements made at the pdD research site. This OOA could be separated into two different types of OOA; OOA1 and OOA2. OOA1 contributed approximately $65 \pm 5 \%$ to the total organic aerosol during all campaigns and had a similar mass spectral signature to OOA measured in Europe and in the United States (Ng et al., 2010, 2011) (Fig. 4). The mass spectral properties of this OOA are defined by having a dominant peak at $\mathrm{m} / \mathrm{z}$ 44 and are generally associated with organic aerosol particles that are aged and have a low volatility. They are therefore termed a low-volatility oxidised organic aerosol particle (LV-OOA).

For the summer campaign the time series of the LV-OOA component showed strongest correlations with that of $\mathrm{O}_{3}$ $\left(r^{2}=0.52\right), \mathrm{CO}\left(r^{2}=0.33\right)$, and BC $\left(r^{2}=0.44\right)$ (Table S1). Ozone has been shown to be a good marker for the production of secondary organic aerosols in some campaigns (Cabada et al., 2004), but other studies show that this is not always the case (Zhang et al., 2005). During the autumn and winter the LV-OOA component showed good correlations $\left(r^{2}>0.50\right)$ with both $\mathrm{NO}_{3}$ and $\mathrm{NH}_{4}$. Correlations between the organic and the inorganic species during the winter suggest that these species have similar sources. However, during the winter boundary layer dynamics are also influencing the time series of all compounds. Unlike all other seasons the LV-OOA showed a strong correlation with $\mathrm{Chl}$ in the winter $(>0.70)$, suggesting that the aerosol is related 

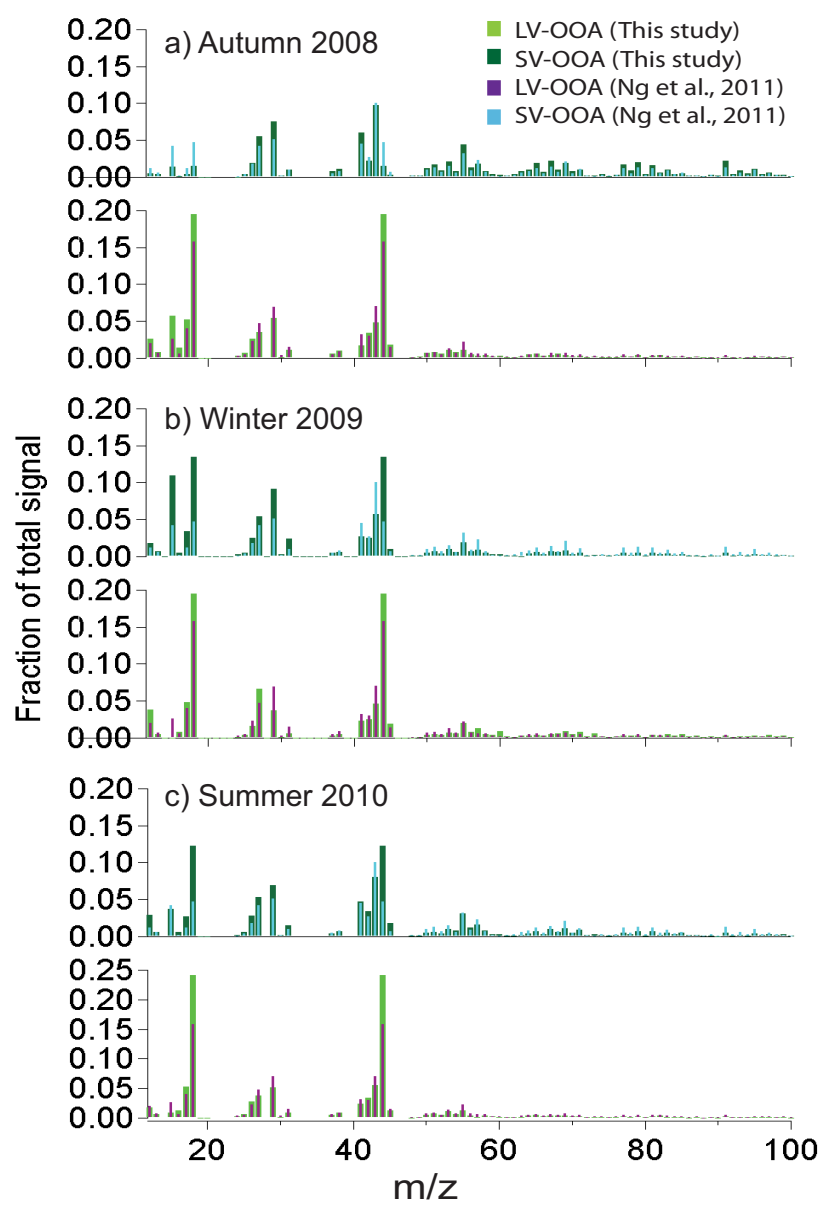

Fig. 3. Average mass spectra of organic species extracted from the total organic mass spectra for the (a) autumn, (b) winter, and (c) summer campaign. Smaller sticks overlayed on each mass spectral pattern represent those of $\mathrm{Ng}$ et al. (2011).

to biomass burning emission sources (DeCarlo et al., 2008). This is confirmed by the similarities of the LV-OOA mass spectra with the reference mass spectra of biomass burning organic aerosol (BBOA), which is due to contributions from $\mathrm{m} / \mathrm{z} 60$ and $\mathrm{m} / \mathrm{z}, 73$, characteristic marker peaks for levoglucason. The weaker correlation between LV-OOA and $\mathrm{SO}_{4}$ during the autumn experiment suggests that some of the $\mathrm{SO}_{4}$ particles may have different sources to that of the organic species. Weak correlations between the organic and inorganic species throughout the summer experiment are a result of the very high mass concentration of the organic species suggesting different sources of the organics to the inorganic species. However, in addition to high organic mass concentration the lack of correlation between the organic and nitrate species is also a result of nitrate chemistry, with nitrate mass concentration decreasing during the day time hours, and the photochemical formation of organic species. Correlations between LV-OOA and BC $\left(r^{2}=0.44\right)$ suggest that some of the LV-OOA may be related to anthropogenic sources. In our

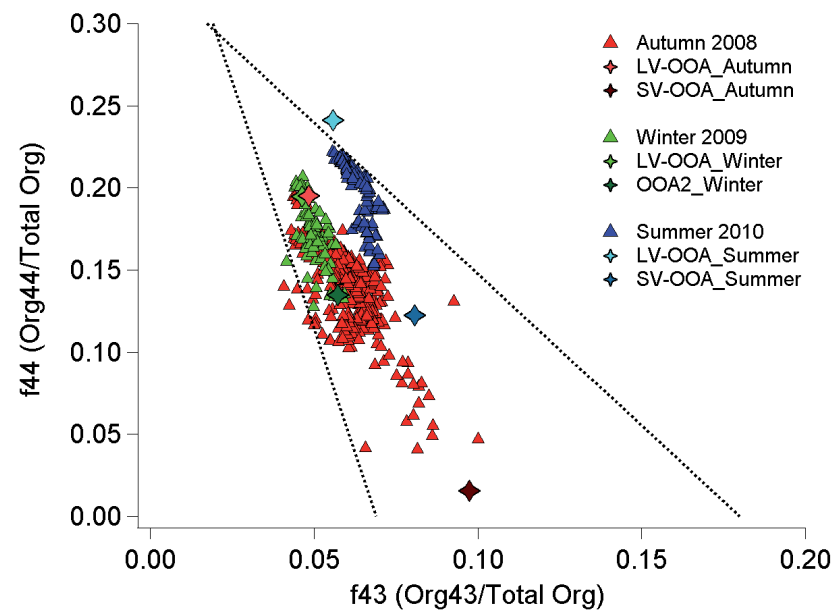

Fig. 4. Plot of the fraction of Org44 to total Organics (f44) against the fraction of Org43 to the total organics (f43) for each campaign. Each triangular point represents data averaged over a 60-min period. The star shaped points show f44 and $\mathrm{f} 43$ of each of the different organic species extracted from the total organic signal using PMF. The black dotted lines show the boundaries set by $\mathrm{Ng}$ et al. (2010).

three campaigns the strongest correlation of LV-OOA with ozone is observed for the summer when high organic mass concentrations were arriving at the pdD site, weaker correlations were observed during autumn and winter $\left(r^{2}<0.01\right.$ and 0.10 , respectively) possibly suggesting a change in the precursor sources to the formation of LV-OOA depending on the season.

Results from the CARBOSOL (study of the present and retrospective state of the organic versus inorganic aerosol over Europe) project (Gelencser et al., 2007), involving organic, levoglucosan, and black carbon measurements from several different European sites show that during the winter months there is a high contribution of biomass burning to secondary organic aerosol particles (Gelencser et al., 2007; Puxbaum et al., 2007; Lanz et al., 2008). We show a high contribution of secondary organic aerosol particles similar to that of fulvic acid during all campaigns, but during the winter campaign the LV-OOA mass spectra also contains marker peaks of wood burning (Alfarra et al., 2007) $(\mathrm{m} / \mathrm{z}$ 60 (contributing $0.9 \%$ to the total mass spectra) and $\mathrm{m} / \mathrm{z} .73$ (contributing $0.7 \%$ to the total mass spectra)) and correlates strongly with the time series of $\mathrm{m} / \mathrm{z} 73$ and $\mathrm{m} / \mathrm{z} 60$. These peak signals suggest that the LV-OOA measured during the winter are possibly related to aged wood burning particles and due to secondary organic aerosols from woodburning emissions which can also contain significant contributions of $m / z 60$ (Heringa et al., 2011). The LV-OOA component had average mass concentrations of $\sim 0.5 \mu \mathrm{g} \mathrm{m}^{-3}$ for most of the winter campaign, but during an isolated 4-h period on 26 February, its mass concentrations increased up to $2 \mu \mathrm{g} \mathrm{m} \mathrm{m}^{-3}$. Organic particle mass concentrations measured during this 
period showed little correlation with gas phase species or other inorganic compounds suggesting that this is an aged aerosol particle type. The residuals measured from the PMF analysis during this period of the winter campaign are higher than during the rest of the campaign. However, a pure primary wood burning factor could not be extracted even when PMF analysis was performed only on this isolated period.

The second type of organic aerosol resolved during each of the campaigns closely resembled a less aged oxidized organic aerosol. The less oxidized organic aerosol particle measured had dominant mass spectral peaks at $\mathrm{m} / \mathrm{z}, 43,44$, 55 , and 57, and was similar to the mass spectra of semivolatile oxidized organic aerosol (SV-OOA) (Ng et al., 2011) (Fig. 3. During the winter campaign, the measured SV-OOA had low concentrations $\left(0.3 \mu \mathrm{g} \mathrm{m}^{-3}\right)$ throughout except for one episode on March 6 when it showed a substantial increase in mass concentration $\left(1.5 \mu \mathrm{g} \mathrm{m}^{-3}\right)$ (Fig. S9). During this episode there was a corresponding increase in nitrate and sulphate particle mass concentrations. The time series of this SV-OOA correlates with the time series of $\mathrm{NO}_{3}$, $\mathrm{BC}$, and with gas phase species $\mathrm{CO}_{2}\left(r^{2}=0.27\right)$ and $\mathrm{NO}_{2}$ $\left(r^{2}=0.48\right)$ suggesting that particles arrived from an anthropogenic source. During the autumn, SV-OOA particles contributed $25 \%$ to the total organic aerosol mass spectra, and correlates well with that of with reference mass spectra for SV-OOA $\left(r^{2}=0.81\right)$ (Fig. 3), and with the time-series of BC $\left(r^{2}=0.12\right)$. Summer SV-OOA contributed $32 \%$ to the overall organic mass. Its mass spectra was well correlated to the literature mass spectra of SV-OOA $\left(r^{2}=0.73\right)$ (Fig. 3 and is also similar to mass spectra of secondary organic aerosols formed from alpha-pinene precursors $\left(r^{2}=0.73\right.$ ) (Bahreini et al., 2005) (Table S1). These correlations suggest that the SV-OOA may be formed from biogenic precursor gases. During the summer campaign there was a steadily increasing temperature under clear sky conditions and there was little contribution from BC $(1.7 \%)$. At the same time, the organic aerosol mass builds steadily with maximum values in the early afternoon on $23,24,25$, and 26 June. The concentrations of all other species (sulphate, ammonium, and nitrate) remain low. These conditions are similar to those observed during a biogenic episode in Egbert, Ontario, Canada (Slowik et al., 2010), the organic mass spectra measured during this event in Canada are similar to our SV-OOA mass spectra (Fig. 2a in Slowik et al., 2010).

Recently, Ng et al. (2010) and Morgan et al. (2010), proposed a method to describe the aging of the OOA component in the atmosphere. Using the fractions of two major mass spectral peaks, $m / z, 44\left(\mathrm{CO}_{2}^{+}\right)$and $m / z, 43\left(\right.$ mostly $\mathrm{C}_{2} \mathrm{H}_{3} \mathrm{O}^{+}$) a triangular space was created in which organic aerosol particles become progressively more aged and move towards the highest point of the triangle during the aging process. For our three campaigns the fraction of $\mathrm{m} / \mathrm{z}$ Org 44 to the total organics (f44) is plotted against the fraction of $\mathrm{m} / \mathrm{z} \operatorname{Org} 43$ to the total organics (f43) (Fig. 4). All of our points and PMF components from each campaign cluster within the well-defined triangular regions as outlined by $\mathrm{Ng}$ et al. (2010). The calculated $\mathrm{f} 44$ and $\mathrm{f} 43$ from each of the PMF components for each campaign is also plotted on the graph. During the autumn, winter, and summer campaign the 444 for LV-OOA organics ranges from 0.19 to 0.24 which is similar to values reported by $\mathrm{Ng}$ et al. (2010) (0.10 to 0.25 ). SV-OOA during the autumn, winter, and summer ranged from 0.02 to 0.14 .

From Fig. 4 it is apparent that aerosol particles measured during the summer are situated on the right side of the graph when it is likely to have more biogenic activity whereas those measured during the winter, when we expect to have the highest contribution from biomass burning, are located on the left side of the triangle. Organic mass spectra measured during the autumn are in the middle. Laboratory studies on secondary organic aerosol formation from biogenic precursors show the resulting $\mathrm{f} 44, \mathrm{f} 43$ on the right side of the $\mathrm{Ng}$ triangle (Jimenez et al., 2009; $\mathrm{Ng}$ et al., 2010), whereas those from biomass burning emissions tend to be situated on the left side of the triangle (Heringa et al., 2011). This is in agreement with our previous discussions where the LV-OOA time series measured during the winter is strongly correlated with that of Chl $\left(r^{2}=0.78\right)$ and has similar mass spectra to reference BBOA mass spectra. For the summer campaign, the high correlations of the measured SV-OOA with the mass spectra of secondary organic aerosol formed from alpha-pinene is in agreement with the hypothesis that the organic mass spectra situated on the right hand side of the graph are likely related to the biogenic precursor sources. However, given its correlation with the time series of $\mathrm{BC}$, the LV-OOA component measured during the summer is likely to also have an anthropogenic source. These observations indicate that the formation of organic aerosol particle is strongly influenced by different processes and precursor sources occurring at different times of the year. The seasonal segregation shown in our measurements of the organic mass spectra suggests that the triangle is not only descriptive for the aging of organic aerosol particles but to some extent can also describe the source of the secondary organic aerosol particles.

\subsection{Diurnal variations and air mass source}

Backward trajectory calculations show that during the autumn and summer campaigns air masses at pdD arrived mainly from the continental sector (39\% Autumn and $80 \%$ Summer), whereas marine airmasses (Marine (29\%)+Marine modified (43\%)) contributed $72 \%$ during the winter. Mediterean air masses were only measured during the autumn campaign where they contributed $13 \%$ to the total airmasses arriving during the sampling period. This air mass pattern is typical of that observed at the pdD station (Venzac et al., 2009). The fractional contribution of each species is averaged during continental, marine, and marine modified air masses, for a given season (Fig. 5). High aerosol mass concentrations are observed during continental air masses $\left(3.3 \mu \mathrm{g} \mathrm{m}^{-3}\right)$, while lowest concentrations 


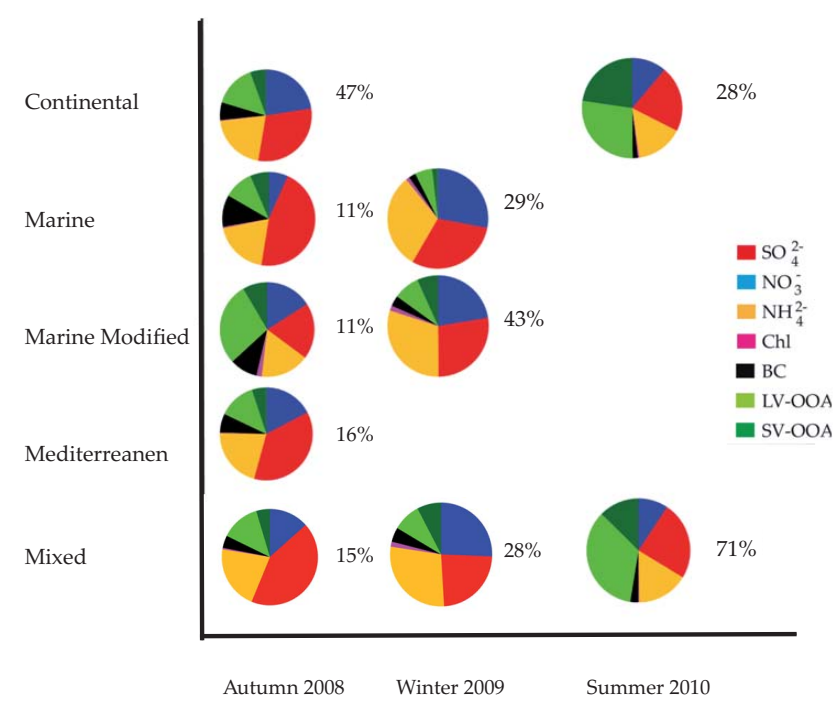

Fig. 5. Particle composition averaged over season and airmass type.

are measured in marine and marine modified air masses $\left(1.2 \mu \mathrm{g} \mathrm{m}^{-3}\right.$ and $2.0 \mu \mathrm{g} \mathrm{m}^{-3}$ respectively), in agreement with Bourcier et al. (2011). Figure 5 illustrates that within a given air mass type the aerosol composition changes significantly with season. Hence, seasonal variability is not solely driven by changes in air mass. Highest fractions of organic and nitrate aerosol particles are observed for continental and marine modified airmasses, organic and sulphate particles are dominant in marine airmasses, particularly during the winter campaign. Despite variability, the organic aerosol particles contribute a large fraction to the overall particle mass whatever the air mass type (20 to $51 \%$ ) or season ( 23 to $50 \%$ ).

One of the conclusions of Lanz et al. (2010) was that the time of year and location of the sampling site could largely explain the variability in chemical composition for different campaigns and was found to be a better description of the aerosol composition than the type of site (rural vs. urban). Here we show that although the time of year has an important influence on the aerosol particle composition, the source of the airmasses still has significant effects on the submicron particle composition.

In earlier studies, the seasonal variability of aerosol properties were shown to be linked to the frequency at which the pdD site was located in the PBL or FT/RL Venzac et al. (2009). The pdD site is mostly in the PBL during the day and FT/RL during the night time hours, particularly during the winter. Figure 6 shows the diurnal variability of the mass concentration of the inorganic and organic species during each campaign. Particle number concentration $\left(N_{\text {tot }}\right)$ measurements made at the site over several years show that in general the typical diurnal variability is characterized by an increase in $N_{\text {tot }}$ between 12:00 and 14:00 UTC (Venzac et al., 2009). In this study we observe that the diurnal variability in

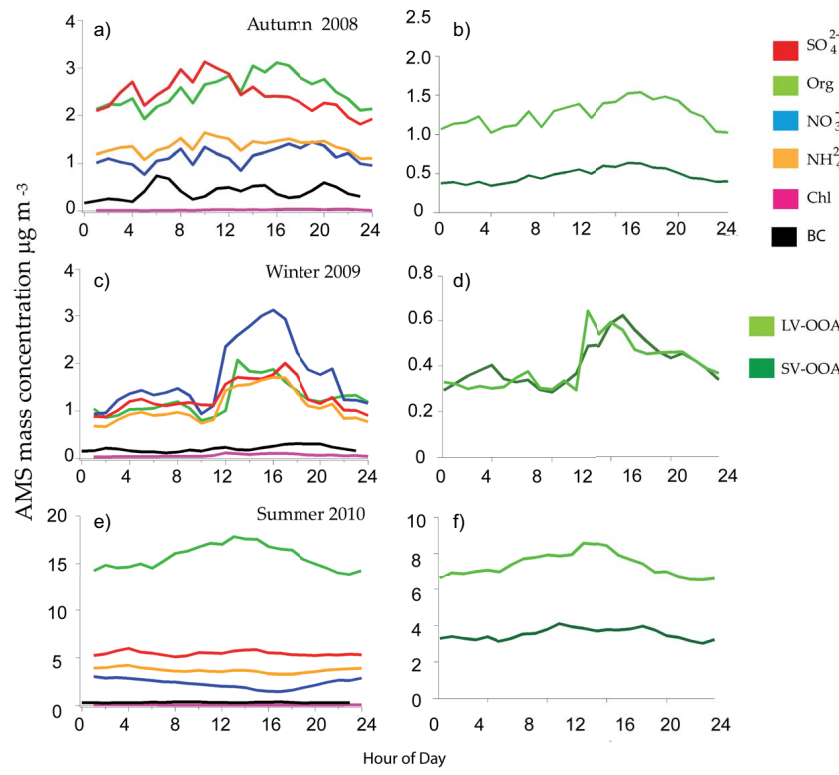

Fig. 6. Diurnal variation of mass concentration of $\mathrm{BC}$ and inorganic and organic particles for autumn, (a) and (b), winter, (c) and (d), and summer, (e) and (f).

$N_{\text {tot }}$ was strongest during the autumn and winter, and weakest during the summer campaign (Table 1). AMS measurements show strongest diurnal variability in particle mass concentrations during the winter (Fig. 6), when the pdD site is expected to spend the majority of the time in the free troposphere and only be advected by boundary layer airmasses for several hours during the day. However, particle mass concentrations show that the FT/RL (night time) aerosol composition is only slightly different from that of the BL (day time).

During autumn and winter we observe increases in the mass concentration of all species during the day and decreases at night. However, the relative contributions of all species do not change. For the summer campaign, mass concentrations of Org and $\mathrm{SO}_{4}^{2}-$ increase while those of $\mathrm{NO}_{3}$ decrease during the daytime hours (Fig. 6). These changes are presumably a result of photochemical secondary aerosol production of organics and sulphates during the day, rather than changes from BL to FT. Summer night time increases in $\mathrm{NO}_{3}$ are likely related to the lower mass concentrations of sulphate at night, allowing excess $\mathrm{NH}_{3}$ to react with nitrate (Seinfeld and Pandis, 1998), this process is also favoured by the lower temperatures and higher RH during the night time. A closer look at the different organic components determined from PMF analysis show that the organic components day time increases are evenly attributed to both LV-OOA and SVOOA. During the summer campaign the diurnal temperature difference was approximately $5{ }^{\circ} \mathrm{C}$, however during autumn and winter it was less than $2{ }^{\circ} \mathrm{C}$. 

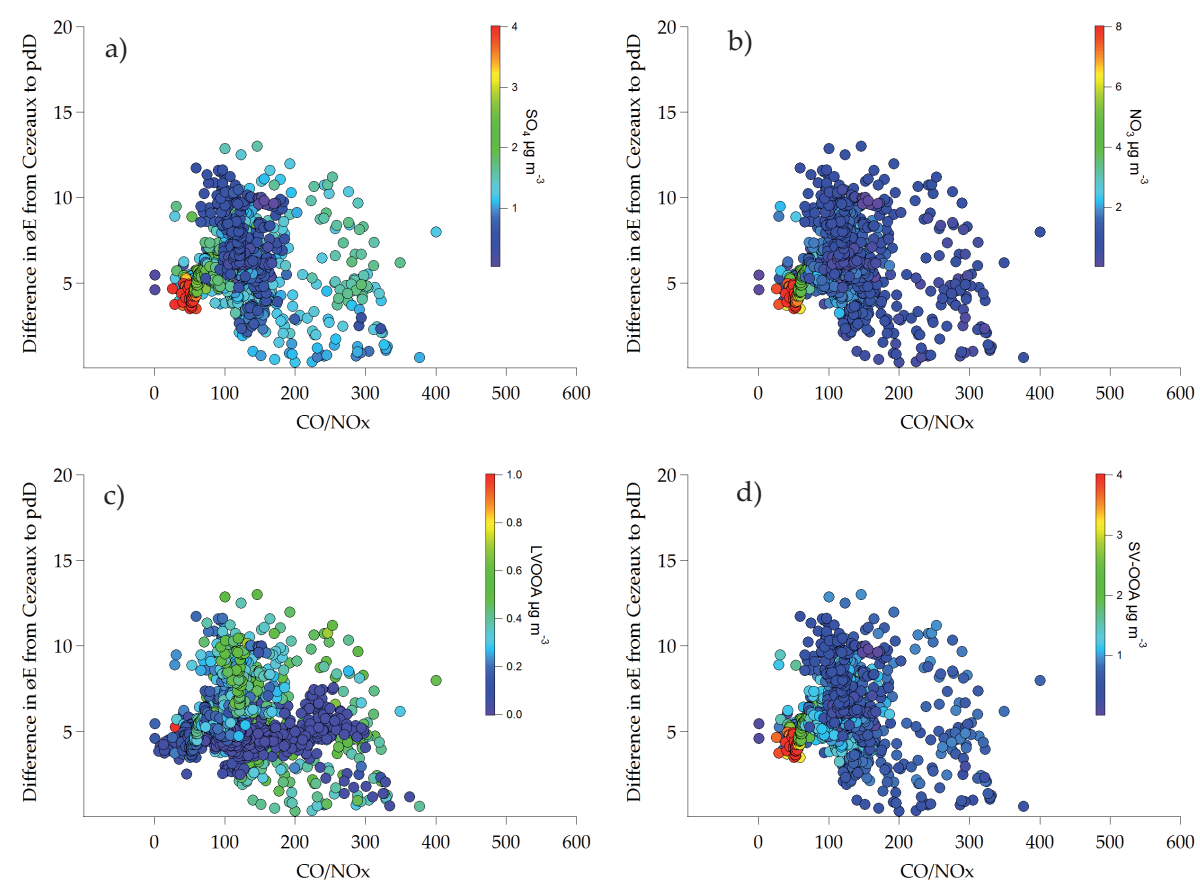

Fig. 7. Difference in $\theta e$ vs the $\mathrm{CO} / \mathrm{NO}_{\mathrm{x}}$ ratio during winter 2009. Plots are coloured by (a) $\mathrm{SO}_{4}$, (b) $\mathrm{NO}_{3}$, (c) $\mathrm{LV}-\mathrm{OOA}$, and (d) $\mathrm{SV}-\mathrm{OOA}$.

The chemical composition of aerosol particles were also examined relative to the age of the air masses. Since $\mathrm{NO}_{\mathrm{y}}$ measurements were not available at the pdD site during these measurements, the ratio of $\mathrm{CO} / \mathrm{NO}_{\mathrm{x}}$ was used as a tracer for major pollution sources and for photochemical processing. According to (Morgan et al., 2010), a value between 10 and 50 for the $\mathrm{CO} / \mathrm{NO}_{\mathrm{x}}$ ratio, is classified as near-source conditions. During all measurement campaigns the $\mathrm{CO} / \mathrm{NO}_{\mathrm{x}}$ ratio range from 7 to greater than 400 with an average value of $93 \pm 43$, confirming that most of the airmasses arriving at the $\mathrm{pdD}$ are representative of aged regional emissions. Plotting the fraction of $\mathrm{SO}_{4}, \mathrm{NO}_{3}, \mathrm{LV}-\mathrm{OOA}$, and SV-OOA to the total aerosol mass concentration against the $\mathrm{CO} / \mathrm{NO}_{\mathrm{x}}$ ratio (Fig. S10), shows that LV-OOA is associated with aged air masses while highest nitrate concentrations favour low $\mathrm{CO} / \mathrm{NO}_{\mathrm{x}}$ ratios arising presumably from boundary layer sources.

The age of the air masses are likely connected to the BL/FT segregation. Hence, on the basis of both thermodynamical and chemical indicators we used a combination of $\theta e$ measurements and gas-phase measurements to characterize the properties of aerosol particles likely associated with $\mathrm{BL} / \mathrm{FT}$ air masses. Plotting the difference in $\theta e(\Delta \theta e)$ against the $\mathrm{CO} / \mathrm{NO}_{\mathrm{x}}$ ratio, we observe that there is not a strong linear relationship between $\theta e$ and the $\mathrm{CO} / \mathrm{NO}_{\mathrm{x}}$ ratio. However, lowest values of $\theta e$ are related to low $\mathrm{CO} / \mathrm{NO}_{\mathrm{x}}$ ratios (Fig. 7) indicating that, overall, the thermodynamical indicator of BL/FT air masses, $\theta e$, is coherent with the chemical aging indicator, $\mathrm{CO} / \mathrm{NO}_{\mathrm{x}}$. These plots suggest that boundary layer air masses can be characterized by low $\theta e$ and low
$\mathrm{CO} / \mathrm{NO}_{\mathrm{x}}$ ratios, whereas airmasses arriving from the free troposphere or residual layer are characterized by high $\theta e$ and high $\mathrm{CO} / \mathrm{NO}_{\mathrm{x}}$ ratios (Fig. 7). If these plots are coloured by particle composition, we observe that high concentrations of $\mathrm{NO}_{3}$ and SV-OOA are most often related to airmasses mostly associated to BL air, whereas highest concentrations of LVOOA are related to air masses associated to residual layer or free tropospheric air.

\section{Conclusions}

This is the first time that the cToF-AMS has been deployed during three seasons at an altitude site, providing a unique opportunity to study the seasonal variability of regional airmasses. Through investigating the chemical composition of submicron aerosol composition during autumn 2008, winter 2009, and summer 2010, we show that although the time of year has a strong influence on the chemical properties of the airmass, we also observe that the source (FT/BL) and transport direction of airmasses influence the properties of aerosol particle. Examining particle mass concentrations together with gas-phase measurements allows us to associate nitrate and less aged organics with airmasses arriving from the BL whereas airmasses arriving from the FT/RL are correlated with aged organics and sulphate particles. Detailed analysis of the organic component showed that two different types of organic aerosol particles were measured at the site: a LV-OOA particle and a SV-OOA particle. The lack of a clear sign of primary contributions to organic mass is similar as 
previously found in Crete (Hildebrandt et al., 2010). Small changes in mass spectral properties between seasons as well as correlations with different gas and particle phase species suggest that there are different precursor sources contributing to the formation of secondary organic aerosols during different seasons of the year. From the analysis of the resolved organic mass spectra we conclude that biomass burning emissions contribute to the formation of secondary organic aerosols during the winter and biogenic emissions contribute during the summer. Considering seasonal influences on the formation of SOA is important in modelling and quantifying organic mass concentrations in the atmosphere. These measurements show that through a combination of continuous aerosol particle measurements, we can understand the influence of different airmass sources (FT/BL) and transport directions on the aging and formation of the aerosol particle distribution, particularly the organic fraction.

\section{Supplementary material related to this article is available online at: http://www.atmos-chem-phys.net/11/13047/2011/ acp-11-13047-2011-supplement.pdf.}

Acknowledgements. We thank Manjula Canagaratna for helpful discussions. This work was performed in the framework of the Research Infrastructure Action under the FP6 Structuring the European Research Area Programme, EUSAAR Contract No. RII3-CT-2006-026140. The work has been partly funded by FP6 Integrated project EUCAARI, Contract no. 36833. E. J. Freney is funded by an AXA postdoctoral fellowship (ACI-AMS) and by a Marie-Curie international reintegration grant.

Edited by: V.-M. Kerminen

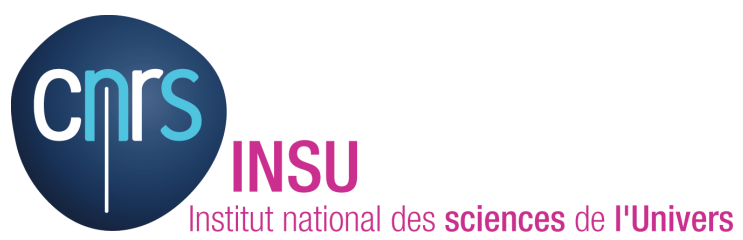

The publication of this article is financed by CNRS-INSU.

\section{References}

Alfarra, M. R., Prevot, A. S. H., Szidat, S., Sandradewi, J., Weimer, S., Lanz, V. A., Schreiber, D., Mohr, M., and Baltensperger, U.: Identification of the mass spectral signature of organic aerosols from wood burning emissions, Environ. Sci. Technol., 41, 57705777, doi:10.1021/es062289b, 2007.

Allan, J. D., Delia, A., Coe, H., Bower, K., Alfarra, M., Jimenez, J., Middlebrook, A., Drewnick, F., Onasch, T., Canagaratna, M., Jayne, J., and Worsnop, D.: A generalised method for the extraction of chemically resolved mass spectra from aerodyne aerosol mass spectrometer data, J. Aerosol Sci., 35, 909-922, doi:10.1016/j.jaerosci.2004.02.007, 2004.
Bahreini, R., Keywood, M., Ng, N., Varutbangkul, V., Gao, S., Flagan, R., Seinfeld, J., Worsnop, D., and Jimenez, J.: Measurements of secondary organic aerosol from oxidation of cycloalkenes, terpenes, and m-xylene using an Aerodyne aerosol mass spectrometer, Environ. Sci. Technol., 39, 5674-5688, doi:10.1021/es048061a, 2005.

Bolton, D.: The computation of equivalent potential temperature, Mon. Weather Rev., 108, 1046-1053, doi:10.1175/15200493(1980)108;1046:TCOEPT ¿2.0.CO;2, 1980.

Bourcier, L., Sellegri, K., Jaffrezo, J.-L., Aymoz, G., Michaud, V., and Laj, P.: Seasonal variation of aerosol chemistry at the puy de Dome station (1465 m.a.s.l), France, in preparation, 2012.

Brooks, I.: Finding boundary layer top: Application of a wavelet covariance transform to lidar backscatter profiles, J. Atmos. Ocean. Tech., 20, 1092-1105, doi:10.1175/15200426(2003)020;1092:FBLTAO;2.0.CO;2, 2003.

Cabada, J., Pandis, S., Subramanian, R., Robinson, A., Polidori, A., and Turpin, B.: Estimating the secondary organic aerosol contribution to $\mathrm{PM}_{2.5}$ using the EC tracer method, Aerosol Sci. Technol., 38, 140-155, doi:10.1080/02786820390229084, 2004.

Canagaratna, M. R., Jayne, J. T., Jimenez, J. L., Allan, J. D., Alfarra, M. R., Zhang, Q., Onasch, T. B., Drewnick, F., Coe, H., Middlebrook, A., Delia, A., Williams, L. R., Trimborn, A. M., Northway, M. J., DeCarlo, P. F., Kolb, C. E., Davidovits, P., and Worsnop, D. R.: Chemical and microphysical characterization of ambient aerosols with the aerodyne aerosol mass spectrometer, Mass Spectrom. Rev., 26, 185-222, doi:10.1002/mas.20115, 2007.

DeCarlo, P. F., Dunlea, E. J., Kimmel, J. R., Aiken, A. C., Sueper, D., Crounse, J., Wennberg, P. O., Emmons, L., Shinozuka, Y., Clarke, A., Zhou, J., Tomlinson, J., Collins, D. R., Knapp, D., Weinheimer, A. J., Montzka, D. D., Campos, T., and Jimenez, J. L.: Fast airborne aerosol size and chemistry measurements above Mexico City and Central Mexico during the MILAGRO campaign, Atmos. Chem. Phys., 8, 4027-4048, doi:10.5194/acp8-4027-2008, 2008.

Drewnick, F., Hings, S., DeCarlo, P., Jayne, J., Gonin, M., Fuhrer, K., Weimer, S., Jimenez, J., Demerjian, K., Borrmann, S., and Worsnop, D.: A new time-of-flight aerosol mass spectrometer (ToF-AMS) - Instrument description and first field deployment, Aerosol Sci. Technol., 39, 637-658, doi:10.1080/02786820500182040, 2005.

Gelencser, A., May, B., Simpson, D., Sanchez-Ochoa, A., KasperGiebl, A., Puxbaum, H., Caseiro, A., Pio, C., and Legrand, M.: Source apportionment of $\mathrm{PM}_{2.5}$ organic aerosol over Europe: Primary/secondary, natural/anthropogenic, and fossil/biogenic origin, J. Geophys. Res.-Atmos., 112, D23S04, doi:10.1029/2006JD008094, 2007.

Heringa, M. F., DeCarlo, P. F., Chirico, R., Tritscher, T., Dommen, J., Weingartner, E., Richter, R., Wehrle, G., Prévôt, A. S. H., and Baltensperger, U.: Investigations of primary and secondary particulate matter of different wood combustion appliances with a high-resolution time-of-flight aerosol mass spectrometer, Atmos. Chem. Phys., 11, 5945-5957, doi:10.5194/acp-11-59452011, 2011.

Hildebrandt, L., Engelhart, G. J., Mohr, C., Kostenidou, E., Lanz, V. A., Bougiatioti, A., DeCarlo, P. F., Prevot, A. S. H., Baltensperger, U., Mihalopoulos, N., Donahue, N. M., and Pandis, S. N.: Aged organic aerosol in the Eastern Mediterranean: 
the Finokalia Aerosol Measurement Experiment - 2008, Atmos. Chem. Phys., 10, 4167-4186, doi:10.5194/acp-10-4167-2010, 2010.

Hock, N., Schneider, J., Borrmann, S., Römpp, A., Moortgat, G., Franze, T., Schauer, C., Pöschl, U., Plass-Dülmer, C., and Berresheim, H.: Rural continental aerosol properties and processes observed during the Hohenpeissenberg Aerosol Characterization Experiment (HAZE2002), Atmos. Chem. Phys., 8, 603-623, doi:10.5194/acp-8-603-2008, 2008.

Hueglin, C., Gehrig, R., Baltensperger, U., Gysel, M., Monn, C., and Vonmont, H.: Chemical characterisation of $\mathrm{PM}_{2.5}$, $\mathrm{PM}_{10}$ and coarse particles at urban, near-city and rural sites in Switzerland, Atmos. Environ., 39, 637-651, doi:10.1016/j.atmosenv.2004.10.027, 2009.

Jimenez, J. L., Canagaratna, M. R., Donahue, N. M., Prevot, A. S. H., Zhang, Q., Kroll, J. H., DeCarlo, P. F., Allan, J. D., Coe, H., Ng, N. L., Aiken, A. C., Docherty, K. S., Ulbrich, I. M., Grieshop, A. P., Robinson, A. L., Duplissy, J., Smith, J. D., Wilson, K. R., Lanz, V. A., Hueglin, C., Sun, Y. L., Tian, J., Laaksonen, A., Raatikainen, T., Rautiainen, J., Vaattovaara, P., Ehn, M., Kulmala, M., Tomlinson, J. M., Collins, D. R., Cubison, M. J., Dunlea, E. J., Huffman, J. A., Onasch, T. B., Alfarra, M. R., Williams, P. I., Bower, K., Kondo, Y., Schneider, J., Drewnick, F., Borrmann, S., Weimer, S., Demerjian, K., Salcedo, D., Cottrell, L., Griffin, R., Takami, A., Miyoshi, T., Hatakeyama, S., Shimono, A., Sun, J. Y., Zhang, Y. M., Dzepina, K., Kimmel, J. R., Sueper, D., Jayne, J. T., Herndon, S. C., Trimborn, A. M., Williams, L. R., Wood, E. C., Middlebrook, A. M., Kolb, C. E., Baltensperger, U., and Worsnop, D. R.: Evolution of Organic Aerosols in the Atmosphere, Science, 326, 1525-1529, doi:10.1126/science.1180353, 2009.

Kasper, A. and Puxbaum, H.: Seasonal variation of SO2, HNO3, NH3 and selected aerosol components at Sonnblick (3106 m asl), Atmospheric environment, 32, 3925-3939, doi:10.1016/S13522310(97)00031-9, 1998.

Lanz, V. A., Alfarra, M. R., Baltensperger, U., Buchmann, B., Hueglin, C., and Prévôt, A. S. H.: Source apportionment of submicron organic aerosols at an urban site by factor analytical modelling of aerosol mass spectra, Atmos. Chem. Phys., 7, 1503-1522, doi:10.5194/acp-7-1503-2007, 2007.

Lanz, V. A., Alfarra, M. R., Baltensperger, U., Buchmann, B., Hueglin, C., Szidat, S., Wehrli, M. N., Wacker, L., Weimer, S., Caseiro, A., Puxbaum, H., and Prevot, A. S. H.: Source attribution of submicron organic aerosols during wintertime inversions by advanced factor analysis of aerosol mass spectra, Environ. Sci. Technol., 42, 214-220, doi:10.1021/es0707207, 2008.

Lanz, V. A., Prévôt, A. S. H., Alfarra, M. R., Weimer, S., Mohr, C., DeCarlo, P. F., Gianini, M. F. D., Hueglin, C., Schneider, J., Favez, O., D'Anna, B., George, C., and Baltensperger, U.: Characterization of aerosol chemical composition with aerosol mass spectrometry in Central Europe: an overview, Atmos. Chem. Phys., 10, 10453-10471, doi:10.5194/acp-10-10453-2010, 2010.

Middlebrook, A., Bahreini, R., Jimenez, J., and Canagaratna, M. R.: Evaluation of Composition-Dependent Collection Efficiencies for the Aerodyne Aerosol Mass Spectrometer using Field Data, Aerosol Sci. Technol., 46, 258-271, doi:10.1080/02786826.2011.620041, 2012.

Morgan, W. T., Allan, J. D., Bower, K. N., Highwood, E. J., Liu, D., McMeeking, G. R., Northway, M. J., Williams, P. I., Krejci,
R., and Coe, H.: Airborne measurements of the spatial distribution of aerosol chemical composition across Europe and evolution of the organic fraction, Atmos. Chem. Phys., 10, 4065-4083, doi:10.5194/acp-10-4065-2010, 2010.

Ng, N. L., Canagaratna, M. R., Jimenez, J. L., Zhang, Q., Ulbrich, I. M., and Worsnop, D. R.: Real-Time Methods for Estimating Organic Component Mass Concentrations from Aerosol Mass Spectrometer Data, Environ. Sci. Technol., 45, 910-916, doi:10.1021/es102951k, 2011.

Ng, N. L., Canagaratna, M. R., Zhang, Q., Jimenez, J. L., Tian, J., Ulbrich, I. M., Kroll, J. H., Docherty, K. S., Chhabra, P. S., Bahreini, R., Murphy, S. M., Seinfeld, J. H., Hildebrandt, L., Donahue, N. M., DeCarlo, P. F., Lanz, V. A., Prévôt, A. S. H., Dinar, E., Rudich, Y., and Worsnop, D. R.: Organic aerosol components observed in Northern Hemispheric datasets from Aerosol Mass Spectrometry, Atmos. Chem. Phys., 10, 46254641, doi:10.5194/acp-10-4625-2010, 2010.

Nyeki, S., Li, F., Weingartner, E., Streit, N., Colbeck, I., Gaggeler, H., and Baltensperger, U.: The background aerosol size distribution in the free troposphere: An analysis of the annual cycle at a high-alpine site, J. Geophys. Res.-Atmos., 103, 31749-31761, doi:10.1029/1998JD200029, 1998.

Paatero, P.: Least squares formulation of robust non-negative factor analysis, Chemometrics and Intelligent Laboratory Systems, 37, 23-35, doi:10.1016/S0169-7439(96)00044-5, 1997.

Paatero, P. and Tapper, U.: Positive matrix factorizationA nonnegative factor model with optimal utilization of error-estimates of data values, Environmetrics, 5, 111-126, doi:10.1002/env.3170050203, 1994.

Puxbaum, H., Caseiro, A., Sanchez-Ochoa, A., Kasper-Giebl, A., Claeys, M., Gelencser, A., Legrand, M., Preunkert, S., and Pio, C.: Levoglucosan levels at background sites in Europe for assessing the impact of biomass combustion on the European aerosol background, J. Geophys. Res.-Atmos., 112, D23S05, doi:10.1029/2006JD008114, 2007.

Seinfeld, J. and Pandis, S.: Atmospheric Chemistry and Physics, from Air Pollution to Climate Change, J. Atmos. Chem., 37, 212-214, doi:10.1023/A:1006483708571, 1998.

Sellegri, K., Laj, P., Dupuy, R., Legrand, M., Preunkert, S., and Putaud, J.-P.: Size-dependent scavenging efficiencies of multicomponent atmospheric aerosols in clouds, J. Geophys. Res.Atmos., 108, 4334, doi:10.1029/2002JD002749, 2003.

Slowik, J. G., Stroud, C., Bottenheim, J. W., Brickell, P. C., Chang, R. Y.-W., Liggio, J., Makar, P. A., Martin, R. V., Moran, M. D., Shantz, N. C., Sjostedt, S. J., van Donkelaar, A., Vlasenko, A., Wiebe, H. A., Xia, A. G., Zhang, J., Leaitch, W. R., and Abbatt, J. P. D.: Characterization of a large biogenic secondary organic aerosol event from eastern Canadian forests, Atmos. Chem. Phys., 10, 2825-2845, doi:10.5194/acp-10-2825-2010, 2010.

Ulbrich, I. M., Canagaratna, M. R., Zhang, Q., Worsnop, D. R., and Jimenez, J. L.: Interpretation of organic components from Positive Matrix Factorization of aerosol mass spectrometric data, Atmos. Chem. Phys., 9, 2891-2918, doi:10.5194/acp-9-2891-2009, 2009.

Venzac, H., Sellegri, K., Villani, P., Picard, D., and Laj, P.: Seasonal variation of aerosol size distributions in the free troposphere and residual layer at the puy de Dôme station, France, Atmos. Chem. Phys., 9, 1465-1478, doi:10.5194/acp-9-1465-2009, 2009.

Weingartner, E., Nyeki, S., and Baltensperger, U.: Seasonal and 
E. J. Freney et al.: Seasonal variations in aerosol particle composition in France

diurnal variation of aerosol size distributions $(10<D<750 \mathrm{~nm})$ at a high-alpine site (Jungfraujoch $3580 \mathrm{~m}$ asl), J. Geophys. Res.Atmos., 104, 26809-26820, doi:10.1029/1999JD900170, 1999.
Zhang, Q., Alfarra, M., Worsnop, D., Allan, J., Coe, H., Canagaratna, M., and Jimenez, J.: Deconvolution and quantification of hydrocarbon-like and oxygenated organic aerosols based on aerosol mass spectrometry, Environ. Sci. Technol., 39, 49384952, doi:10.1021/es0485681, 2005. 